\title{
Acacia etbaica as a Potential Low-Cost Adsorbent for Removal of Organochlorine Pesticides from Water
}

\author{
Abraha Gebrekidan ${ }^{1 *}$, Mekonen Teferi ${ }^{2}$, Tsehaye Asmelash ${ }^{3}$, Kindeya Gebrehiwet ${ }^{4}$, \\ Amanual Hadera1, Kassa Amare ${ }^{5}$, Jozef Deckers', Bart Van Der Bruggen ${ }^{7}$ \\ ${ }^{1}$ Department of Chemistry, Mekelle University, Mekelle, Ethiopia \\ ${ }^{2}$ Department of Biology, Mekelle University, Mekelle, Ethiopia \\ ${ }^{3}$ Department of Microbiology, Mekelle University, Mekelle, Ethiopia \\ ${ }^{4}$ Department of Land Resource Management \& Environmental Protection, Mekelle University, Mekelle, \\ Ethiopia \\ ${ }^{5}$ Department of Earth Science, Mekelle University, Mekelle, Ethiopia \\ ${ }^{6}$ Department for Earth and Environmental Science, KU Leuven, Leuven, Belgium \\ ${ }^{7}$ Department of Chemical Engineering, Process Engineering for Sustainable Systems (ProcESS), KU Leuven, \\ Leuven, Belgium \\ Email: ${ }^{*}$ abrishgk@yahoo.com
}

Received 7 February 2015; accepted 24 February 2015; published 27 February 2015

Copyright (C) 2015 by authors and Scientific Research Publishing Inc.

This work is licensed under the Creative Commons Attribution International License (CC BY).

http://creativecommons.org/licenses/by/4.0/

c) (i) Open Access

\section{Abstract}

The presence of pesticides in the environment is of great concern due to their persistent nature and chronic adverse effect on human health and the environment. Water bodies are subject to pollution by organochlorine pesticides, especially in developing countries, where water pollution is a key sustainability challenge. Hence, activated carbon is considered a universal adsorbent for the removal of organochlorine pollutants from water. Activated carbon from Acatia etbaica was prepared using traditional kilns with low investment costs. Pesticides such as aldrin, dieldrin and DDT were selected for adsorption because of their common usage in agricultural and malaria control activities and may occur in high concentrations in surface waters that are used as drinking water sources. The effect of the adsorbent dose and initial concentration were investigated. To describe the equilibrium isotherms the experimental data were analyzed by the Langmuir and Freundlich isotherm models. The Freundlich model gave the best correlation with the experimental data. Activated carbon prepared from Acacia etbaica was found to be an effective and low-cost alternative for the removal of organochlorine pesticides from aqueous solutions. The preparation method allows the use of this material by local communities for effective remediation of pollution

*Corresponding author.

How to cite this paper: Gebrekidan, A., Teferi, M., Asmelash, T., Gebrehiwet, K., Hadera, A., Amare, K., Deckers, J. and Van Der Bruggen, B. (2015) Acacia etbaica as a Potential Low-Cost Adsorbent for Removal of Organochlorine Pesticides from Water. Journal of Water Resource and Protection, 7, 278-291. http://dx.doi.org/10.4236/jwarp.2015.73022 


\section{by pesticides.}

\section{Keywords}

Acacia etbaica, Activated Carbon, Organochlorine Pesticides, Adsorption, Water Purification

\section{Introduction}

Surface water bodies are subject to pollution by organochlorine pesticides, especially in developing countries, where the safety of surface water bodies is closely related to human health [1]. Contamination of water resources by pesticide residues is a key sustainability challenge [2]. Their extensive use in world-wide agricultural practice in addition to industrial emission during their production has led to substantial occurrence of pesticide residues and their metabolites in food commodities, water and soil [3]. The presence of organochlorine pesticides in the environment is of great concern due to their persistent nature and chronic adverse effect on human health and the environment [4]-[7]. Many organochlorines have been implicated in a broad range of adverse human health and environmental effects, including impaired reproduction, endocrine disruption, immunosuppression, attacks nervous systems, convulsion, liver damage, carcinogenic and destroys enzymatic activities [8]-[15].

Organochlorine pesticides have been widely used around the world to boost agricultural crop yield and to control vector-borne diseases [16]-[18]. While many organochlorine pesticides have been banned in the developed countries for several decades, they continue to be used in some parts of Africa [19]. The early spectacular success of dichlorodiphenyl-trichloroethane (DDT) for malaria control in some countries has resulted in a continued use of this insecticide in developing countries, including Ethiopia [20] [21].

A number of technologies are available to control water pollution [22]. Some of them are coagulationflocculation [23], anaerobic biodegradation [24] [25], photodegradation [26], ozonization [27], ion exchange [28], advanced oxidation processes [29] [30], nanofiltration [31] [32] and adsorption on different activated carbons [28] [33]-[35]. However, most of them require substantial financial input and their use is often restricted because of cost factors overriding the importance of pollution control. This makes their application unfeasible for local communities in non-industrialized countries. Among various available water treatment technologies, adsorption is considered one of the most feasible processes because of its convenience, ease of operation and simplicity of design [36]. This process can remove/minimize different types of pollutants and thus it has a wider applicability in water pollution control [37].

Activated carbon is considered a universal adsorbent for the removal of diverse types of pollutants from water [38]. However, widespread use of commercial activated carbon is restricted for small-scale, often remote communities due to its high cost [39]. Attempts have been made to develop inexpensive adsorbents utilizing numerous agro-industrial and municipal waste materials. The use of waste materials as low-cost adsorbents is attractive due to their contribution in the reduction of costs for waste disposal, therefore contributing to environmental protection. Some of the low-cost alternative adsorbents used include bamboo and coconut shell [40], cactus [41], rice husk [42], bamboo canes, peanut shells, olive stones, avocado stones, date stones, straw, wood sawdust [43], agave bagasse [44], rice bran, rice husk, bagasse fly ash of sugarcane, Moringa oleifera pods [45], sheep manure and spent coffee grounds [46], date and olives stones [47], oil palm shell [48], and coconut [49].

Acacia etbaica (A. etbaica) belongs to the Fabaceae-Mimosoideae family of plants and is also known as arrad (in Arabic), mgunga (in Swahili) and seraw (in Tigrigna) (Agroforestry tree data base). Acacia etbaica occurs in dry bush land, thickets, semi-desert scrub and wooded grasslands. Countries where this crop is commonly known are Eritrea, Ethiopia, Kenya, Somalia, Sudan, Tanzania, and Uganda; however, it is also found elsewhere. Acacia etbaica is widely used as a source of firewood. The tree is also widely used to make the pillars and beams of earthen houses in northern Ethiopia [50] and as a medicine where its bark is chewed as a stimulant and is also used in the treatment of gonorrhea. Yet, this locally available resource has not been studied for its use in water treatment.

The purpose of this work is not only to develop a low-cost method that can be used in remote communities, but also to evaluate the adsorption capacity of $A$. etbaica-based activated carbon in removing trace levels of organic 
pollutants from aqueous solution. None have been recorded on the adsorption of organochlorine pesticides using A. etbaica activated carbon and used to embark on this investigation. Organochlorine pesticides of aldrin, dieldrin and DDT were selected for this study, since they are a critical threat for local communities in developing countries. They are toxic and their application has been banned worldwide. Despite this, most are widely used in many developing countries for the control of mosquitos, harmful soil insects and plant pests [51]. The adsorption capacity of A. etbaica-based activated carbon was compared to that of commercial activated carbon.

\section{Materials and Methods}

\subsection{Activated Carbon}

The granulated activated carbons were selected from two raw materials: commercial activated carbon (CAC) (NORIT N.V, Amersfoort-The Netherlands) and activated carbon made from A. etbaica (AEAC) (locally made in Ethiopia). The commercial activated carbon was used as a reference in comparison with the local activated carbon. Acacia etbaica was obtained from local villages, where it is mainly used as energy source.

\subsection{Preparation of Activated Carbon}

Dry wood logs of A. etbaica was cut into pieces, 50 - $100 \mathrm{~cm}$ size, and buried in earth-covered traditional kilns for weeks, where wood is cut and stacked before being covered in earth and carbonized. The kilns are practical with low-investment options for poor producers. The charcoal was ground in a high-speed rotary cutting mill and sieved into different mm sizes. Before the application of the charcoal to our research it was washed several times with distilled water to remove dust and some other residuals. The washed samples were dried at room temperature and packed in an air tight container.

For better understanding the surface properties, both commercial and locally made activated carbon was examined using scanning electron microscopy (Philips XL 30 FEG SEM, at $10 \mathrm{keV}$, The Netherlands).

For the determination of metal content, $0.1 \mathrm{~g}$ of adsorbent sample was mixed with $5 \mathrm{~mL}$ of $70 \%$ nitric acid in a plastic beaker and gently boiled for 15 minutes. When no more brown fumes of $\mathrm{NO}_{2}$ were observed, $5 \mathrm{~mL}$ of perchloric acid was added and gentle boiling continued until almost all material had dissolved. The mixture was then filtered and washed three times with distilled water. The filtrate and washings were diluted to $100 \mathrm{~mL}$ with de-ionized water. The solution obtained was analyzed for metal content using ICP-MS ('Thermo X Series 1, Thermo Fischer Scientific, Belgium). The methods of detection limits (MDLs) for ICP-MS used for the analysis of most elements and their limits of quantification was $1 \mu \mathrm{g} / \mathrm{L}$ with the relative standard deviation (RSD \%) value 3.0\%. T-test for the elemental composition of the adsorbents was performed using SAS 9.2.

\section{Chemicals}

Analytical grade chemicals were used during the experiment: aldrin, dieldrin, DDT and trifluralin (Sigma Aldrich, Belgium), methanol (VWR, Belgium), dichloromethane (Fisher Scientific, Belgium), anhydrous sodium sulphate (ACROS, Belgium), nitric acid (Fisher Scientific, Belgium), perchloric acid (Fisher Scientific, Belgium).

\subsection{Sample Preparation}

Test solutions of organochlorine pesticides were prepared by serial dilution of stock solutions using methanol (VWR, Belgium). The concentrations of pesticides added to the water samples ranged from 1 to $1000 \mu \mathrm{g} / \mathrm{L}$, to simulate actual concentrations in surface water up to extreme circumstances [23]. Stock solutions of trifluralin (200 mg/L) were also prepared as an internal standard using methanol.

\subsection{Instrumentation}

The extracted pesticides were analyzed by gas chromatography (GC) on a Perkin Elmer Auto System XL and a Perkin Elmer electron capture detector (ECD). The column used was CP-Sil 8CB (Chromopack, WCOT Fused Silica, $50 \mathrm{~m} \times 0.25 \mathrm{~mm}$, ID $=0.4$, Holland). All GC analyses were carried out at $260^{\circ} \mathrm{C}, 250^{\circ} \mathrm{C}$ and $275^{\circ} \mathrm{C}$ for column, injector and detector, respectively, in a total run time of $40.5 \mathrm{~min} / \mathrm{sample}$. The mobile phase used was nitrogen at a flow rate of $60 \mathrm{~mL} / \mathrm{min}$. 


\subsection{Batch Adsorption Experiments}

Batch equilibrium adsorption experiments were performed using $100 \mathrm{~mL}$ of spiked pesticide aqueous solutions. After the adsorption process, the adsorbent was separated from the samples by filtering and pre-concentrated using liquid-liquid extraction. Two extractions with $35 \mathrm{~mL}$ of dichloromethane (Fisher Scientific) were carried out for each sample. To control for losses during extraction, $5 \mu \mathrm{L}$ of $100 \mathrm{mg} / \mathrm{L}$ trifluralin (Sigma Aldrich) was added as an internal standard to each sample. The extracts were combined and dried with anhydrous sodium sulphate (ACROS). The extracts were concentrated to $1-2 \mathrm{~mL}$ by evaporation at $65^{\circ} \mathrm{C}$ in a Kuderna-Danish flask. The samples were kept in a refrigerator at $4^{\circ} \mathrm{C}$ until analysis.

We investigated the effects on adsorption of the organochlorine pesticides onto A. etbaica derived and commercial activated carbon of adsorption parameters such as particle size $(0.25-2 \mathrm{~mm})$, adsorbent dose (2.5, 5.0, 7.5, and $10.0 \mathrm{~g} / \mathrm{L}$ ), initial pesticides concentration $(10,25,50,100,250 \mu \mathrm{g} / \mathrm{L})$, contact time (120 min) were studied at room temperature and $\mathrm{pH} 7$ in a batch mode of operation.

The amount of pesticide adsorbed per weight unit of activated carbon, $\mathrm{q}_{\mathrm{e}}$, was calculated using the Equation (1):

$$
q_{e}=\frac{\left(C_{o}-C_{e}\right) V}{W}
$$

where $C_{o}$ and $C_{e}$ are the pesticide concentration measured before and after adsorption $(\mu \mathrm{g} / \mathrm{L}), \mathrm{V}$ is the volume of aqueous solution (L) and $\mathrm{W}$ is dry weight of the adsorbent (g). Two replicates per sample were done and the average results were used. By quantifying the pesticide concentration before and after adsorption, the efficiency of adsorption of pesticide by activated carbon was calculated by using Equation (2):

$$
\operatorname{Adsorption}(\%)=\frac{C_{o}-C_{e}}{C_{o}} \times 100
$$

\subsection{Column Application}

The column experiment was carried out using filter funnel columns (KU Leuven, C. G. B.) with an internal diameter of $2.5 \mathrm{~mm}$ and a bottom with a pore size less than $0.25 \mathrm{~mm}$ not to lose any adsorbent material. The columns were made of transparent glass, and had a height of $210 \mathrm{~mm}$. These columns were filled with varied doses of 3, 5, 7, 9 and $11 \mathrm{~g}$ of 0.25 - $0.5 \mathrm{~mm}$ size AEAC adsorbents. Prior to column filtration, the turbidity of the adsorbent material were removed by flushing of distilled water through the adsorbent. Then, the column was used for sample filtration. In these experiments, a substantially lower concentration of pesticides $20 \mu \mathrm{g} / \mathrm{L}$ of each component was applied in order to approach realistic concentrations in surface waters. Each time $25 \mathrm{~mL}$ of water spiked with $20 \mu \mathrm{g} / \mathrm{L}$ of pesticides (aldrin, dieldrin and DDT) was flushed through the column and the amount of pesticides in the effluent determined. The small-scale column tests were performed in a laboratory set-up by adjusting a constant flow rate at room temperature. Through this the breakthrough curve of the AEAC was also determined.

\subsection{Determination of Adsorption Isotherms}

Adsorption isotherms are equilibrium relationships between the concentration of the adsorbed pesticides and their concentration retained in the solution at a given temperature. The adsorption isotherm experiments were conducted on the basis of batch experiments [2] [52]. In this study, Langmuir and Freundlich isotherm models were used to investigate the adsorption equilibrium between the pesticides solution and activated carbon phase.

The Langmuir model is a non-linear model that suggests a monolayer uptake of the pesticides on a homogenous surface, having uniform energies of adsorption for all the binding sites without any interaction between the adsorbent molecules [53]. The linear form of the Langmuir isotherm [54] [55] is represented by the following equation:

$$
\frac{C_{e}}{q_{e}}=\frac{C_{e}}{Q_{o}}+\frac{1}{b Q_{o}}
$$

where $C_{e}(\mu \mathrm{g} / \mathrm{L})$ is the equilibrium concentration, $Q_{o}(\mu \mathrm{g} / \mathrm{g})$ the monolayer capacity of the adsorbent, and $b$ 
(L/pg) is the Langmuir adsorption constant. A plot of $C_{e} / q_{e}$ versus $C_{e}$ gives $Q_{o}$ and $b$ if the isotherm follows the Langmuir model.

The Freundlich isotherm is an empirical model that is based on adsorption on heterogeneous surface and active sites with different energy. The linearized Freundlich isotherm [56] is represented by the following equation:

$$
\log q_{e}=\log K_{F}+\left(\frac{1}{n}\right) \log C_{e}
$$

where $q_{e}$ is the amount of adsorbed analyte $(\mu \mathrm{g} / \mathrm{g}), C_{e}$ is the equilibrium concentration of the adsorbate ( $\mu \mathrm{g} / \mathrm{L}$ ) and $K_{F}\left(\mu \mathrm{g} / \mathrm{g}(\mathrm{L} / \mu \mathrm{g})^{1 / \mathrm{n}}\right.$ and $1 / n$ are Freundlich constants related to adsorption capacity of the adsorbents and surface heterogeneity. When $\log q_{e}$ is plotted against $\log C_{e}$ and data are analyzed by linear regression, $1 / n$ and $K_{\mathrm{F}}$ constants can be determined from the slope and intercept, respectively [2] [56] [57].

\section{Results and Discussion}

\subsection{Characterization of Activated Carbon}

Since adsorption is a surface phenomenon, the rate and extent of adsorption specific to a given adsorbent are influenced by the physico-chemical characteristics of the adsorbent such as surface area, pore size, surface chemistry and elemental composition [58]. Table 1 represents the elemental composition of the adsorbents AEAC and CAC used during the analysis. The locally prepared activated carbon, AEAC, is rich in calcium and potassium and that the CAC is rich in magnesium, sodium, iron and manganese. Both carbon adsorbents (AEAC and CAC) exhibit similar trace metal concentrations except in sodium, potassium, magnesium, calcium, iron and manganese that shows a significance difference at $\mathrm{p}<0.05$ (Table 1 ).

Scanning electron microscopy (SEM) was used to observe the surface physical morphology of the adsorbents. SEM micrographs of AEAC and CAC are given in Figure 1. Examination of the SEM micrograph showed that a thick wall structure exists along with a well developed wider porosity for both adsorbents, indicating that the external surfaces of the adsorbent materials are full of cavities. The SEM images of the adsorbents indicate a very large surface area in both adsorbents, suggestive of a high adsorption capacity for microorganic pollutants [34].

\subsection{Effect of Adsorbent Dose}

The adsorbent dose is an important parameter because this parameter determines the capacity of adsorbent for a given adsorbate concentration and also determines sorbent-sorbate equilibrium of the system [59]. The effect of the adsorbent dose on the removal of pesticides was studied by varying the dose of the adsorbent from 2.5 - 10.0 $\mathrm{g} / \mathrm{L}$. The experiments were carried out at fixed pesticide concentration of $250 \mu \mathrm{g} / \mathrm{L}$, at room temperature $\left(25^{\circ} \mathrm{C}\right)$

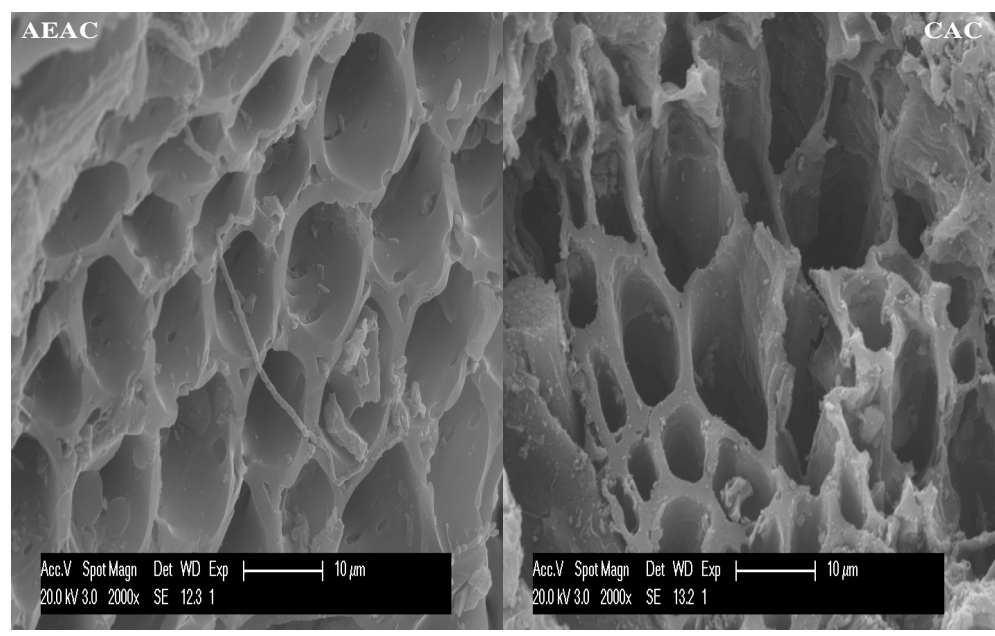

Figure 1. SEM images of AEAC and CAC. 
Table 1. Metal content (Mean \pm standard deviation, in $\mu \mathrm{g} / \mathrm{g}$ ) of AEAC and CAC.

\begin{tabular}{cccccccccc}
\hline $\begin{array}{c}\text { Type of } \\
\text { adsorbent }\end{array}$ & $\mathrm{Na}$ & $\mathrm{Mg}$ & $\mathrm{Si}$ & $\mathrm{K}$ & $\mathrm{Ca}$ & $\mathrm{V}$ & $\mathrm{Cr}$ & $\mathrm{Fe}$ & $\mathrm{Mn}$ \\
\hline AEAC & $15 \pm 1$ & $160 \pm 18$ & $631 \pm 146$ & $281 \pm 32$ & $5305 \pm 495$ & $25 \pm 4$ & $10 \pm 4$ & $118 \pm 31$ & $3 \pm 0.7$ \\
$\mathrm{CAC}$ & $155 \pm 13$ & $850 \pm 28$ & $661 \pm 331$ & $94 \pm 6$ & $897 \pm 54$ & $26 \pm 3$ & $13 \pm 8$ & $220 \pm 12$ & $6 \pm 0.4$ \\
p-value & 0.003 & $<0.0001$ & 0.893 & 0.008 & 0.004 & 0.734 & 0.660 & 0.019 & 0.005 \\
$\begin{array}{c}\text { Type of } \\
\text { adsorbent }\end{array}$ & $\mathrm{Co}$ & $\mathrm{Ni}$ & $\mathrm{Cu}$ & $\mathrm{Zn}$ & $\mathrm{Mo}$ & $\mathrm{Cd}$ & $\mathrm{Sn}$ & $\mathrm{Pb}$ & $\mathrm{As}$ \\
AEAC & $0.1 \pm 0.02$ & $2.8 \pm 1$ & $0.9 \pm 0.07$ & $3.9 \pm 1$ & $0.2 \pm 0.03$ & $<\mathrm{LOD}$ & $0.1 \pm 0.03$ & $0.2 \pm 0.04$ & $<\mathrm{LOD}$ \\
CAC & $0.1 \pm 0.01$ & $1.1 \pm 0.21$ & $2.7 \pm 1.9$ & $6.0 \pm 2$ & $0.2 \pm 0.05$ & $<\mathrm{LOD}$ & $0.2 \pm 0.07$ & $0.4 \pm 0.2$ & $<\mathrm{LOD}$ \\
p-value & 0.359 & 0.447 & 0.253 & 0.202 & 0.195 & - & 0.062 & 0.245 & - \\
\hline
\end{tabular}

and $\mathrm{pH}$ 7. The percentage of pesticides adsorption with varying amounts of adsorbents (AEAC and CAC) is presented in Figure 2. It is evident that the adsorbent dose substantially influences the amount of pesticides adsorbed. The increase in the amount of pesticides adsorbed was found to be high when the amount of adsorbent was increased from 2.5 to $5.0 \mathrm{~g} / \mathrm{L}$ (Figure 2). Further increase of the adsorbent dose resulted in a small increase in adsorption. $7.5 \mathrm{~g} / \mathrm{L}$ is considered the optimum dose. The initial rise in adsorption with adsorbent dose is probably due to greater surface area and the availability of more adsorption sites while the number of adsorbate molecules is constant [60] [61]. The decrease in adsorption of organochlorine pesticides per unit mass of adsorbent, $q_{e}(\mu \mathrm{g} / \mathrm{g})$ that was observed as the dose of adsorbent was increased might be due to interference between binding sites of AEAC and CAC doses [59] [62] [63]. A behavior similar to this has also been observed by Ozcan et al. [62] for adsorption of organochlorine pesticides from aqueous solution. Therefore, as it is seen in Figure 2, the percent of adsorption of pesticides increased with adsorbent dosage, whereas the amount adsorbed per unit mass of adsorbent $\left(\mathrm{q}_{\mathrm{e}}\right)$ decreased. Above $7.5 \mathrm{~g} / \mathrm{L}$ of adsorbent dose, no change in adsorption capacity was observed, which can be attributed to saturation at the exterior surface and the repulsive forces among the pesticide molecules [64]. The locally prepared activated carbon has a good adsorption capacity for the organochlorine pesticides. As clearly seen in Figure 2, it was found to have adsorption capacities almost equal to commercial activated carbon. Hence, A. etbiaca can be used as a low-cost effective adsorbent as an alternative to commercial activated carbon for removal of the organochlorine pesticides from water.

\subsection{Effect of Initial Pesticide Concentration}

Adsorption of organochlorine pesticides (aldrin, dieldrin and DDT) from aqueous solution onto AEAC and CAC was measured for five different initial concentrations $(10,25,50,100$, and $250 \mu \mathrm{g} / \mathrm{L})$ at an adsorbent dosage of $10 \mathrm{~g} / \mathrm{L}$. The effect of the initial concentration of pesticides on the amount of adsorption is shown in Figure 3. The equilibrium adsorption efficiency of AEAC decreases as the initial pesticides concentration increases, while the equilibrium adsorption efficiency for CAC increases slightly with increasing pesticides concentration up to $100 \mu \mathrm{g} / \mathrm{L}$ for aldrin and dieldrin and up to $50 \mu \mathrm{g} / \mathrm{L}$ for DDT. Then the adsorption efficiency decreases as initial pesticides concentration increases. This change likely reflects a reduction of the ratio of available adsorption sites on the adsorbent and pesticide molecules in solution as pesticide concentration increases. A percentage pesticide removal of $97.85 \%$ for aldrin, $91.67 \%$ for dieldrin and $97.41 \%$ for DDT was found for an initial concentration of $10 \mu \mathrm{g} / \mathrm{L}$ on AEAC, and of 99.92\% for aldrin, 99.81\% for dieldrin for an initial concentration of $100 \mu \mathrm{g} / \mathrm{L}$, and $99.80 \%$ for DDT for an initial concentration of $50 \mu \mathrm{g} / \mathrm{L}$ on CAC.

\subsection{Adsorption Isotherms}

The Langmuir and Freundlich isotherm parameters for adsorption of organochlorine pesticides (Aldrin, Dieldrin and DDT) on AEAC and CAC are given in Table 2. The linear isotherms of Langmuir and Freundlich models are also presented in Figure 4 and Figure 5, respectively. Comparison of the $\mathrm{R}^{2}$ values shows that the Freundlich isotherm fits well with the experimental data obtained from both adsorbents (AEAC and CAC). The Freundlich equation had correlation coefficients $\left(\mathrm{R}^{2}\right)$ above 0.98 for the AEAC and above 0.91 for the CAC, 

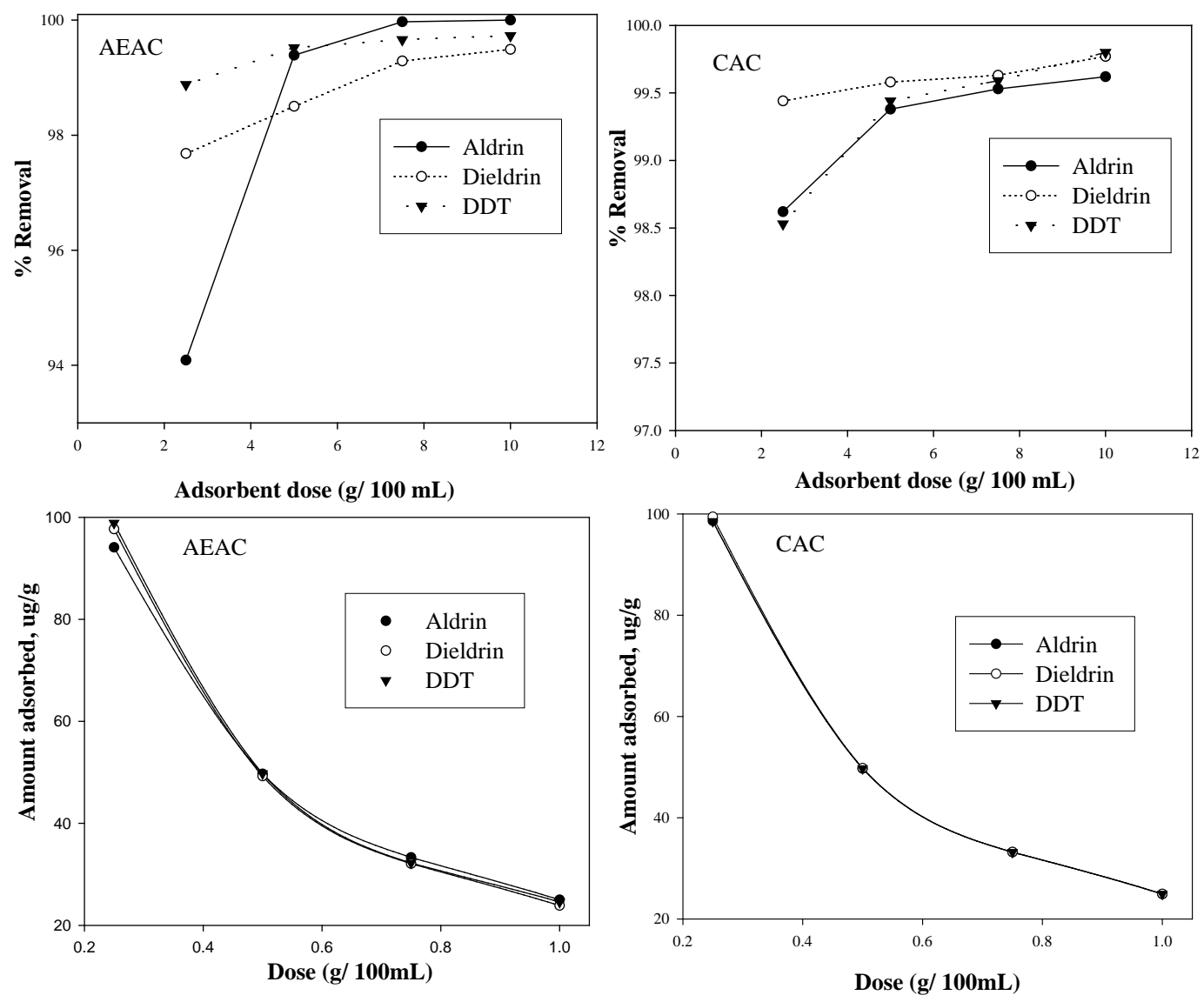

Figure 2. Effect of adsorbent dose on the removal of aldrin, dieldrin and DDT onto AEAC and CAC (temperature: $25^{\circ} \mathrm{C}$, initial concentration $250 \mu \mathrm{g} / \mathrm{L} ; \mathrm{pH} 7$ and time $=2 \mathrm{~h}$ ).
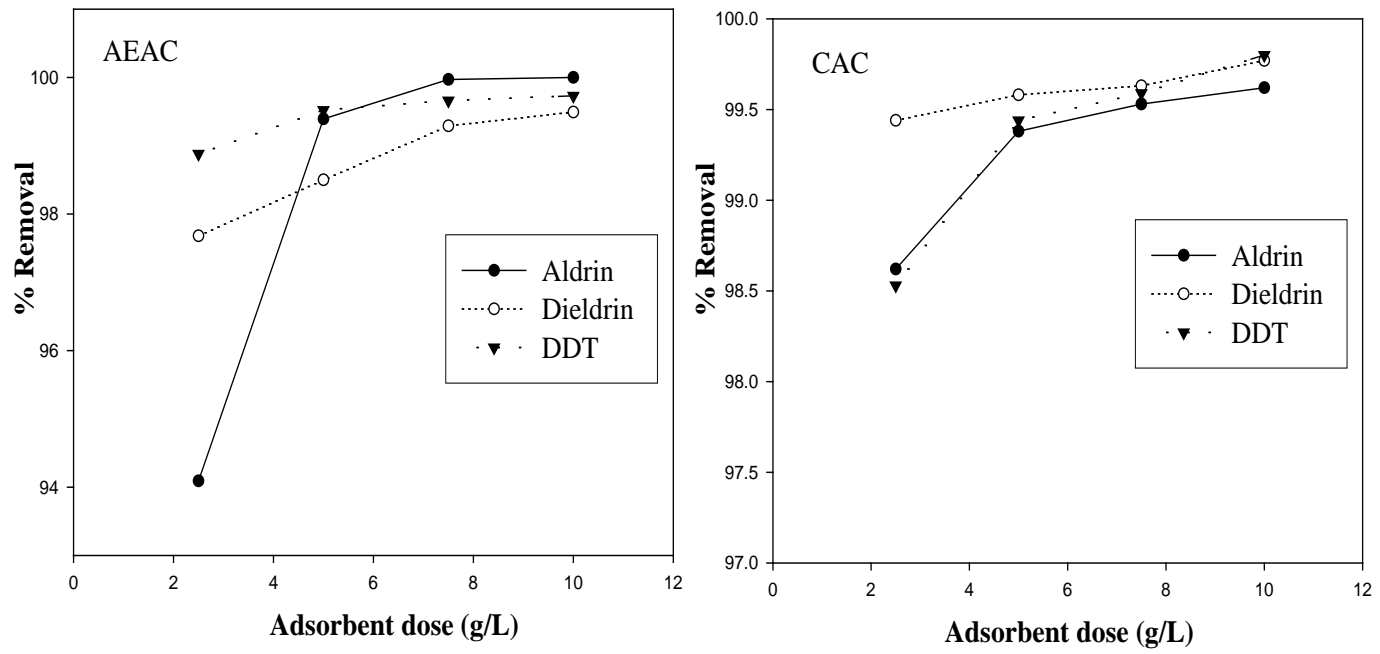

Figure 3. Effect of initial pesticides concentration for adsorption of aldrin, dieldrin and DDT onto AEAC and CAC (the initial pesticides concentration $=10$ to $250 \mu \mathrm{g} / \mathrm{L}$, temperature $25^{\circ} \mathrm{C}$ and time $=2 \mathrm{~h}$ ).

with a high correlation coefficient for the locally prepared activated carbon. This result suggests the formation of multilayer coverage of the organochlorine pesticides (aldrin, dieldrin and DDT) at the surface of the two activated carbons, which is attributed to the heterogeneous active sites on the surface of AEAC and CAC. 

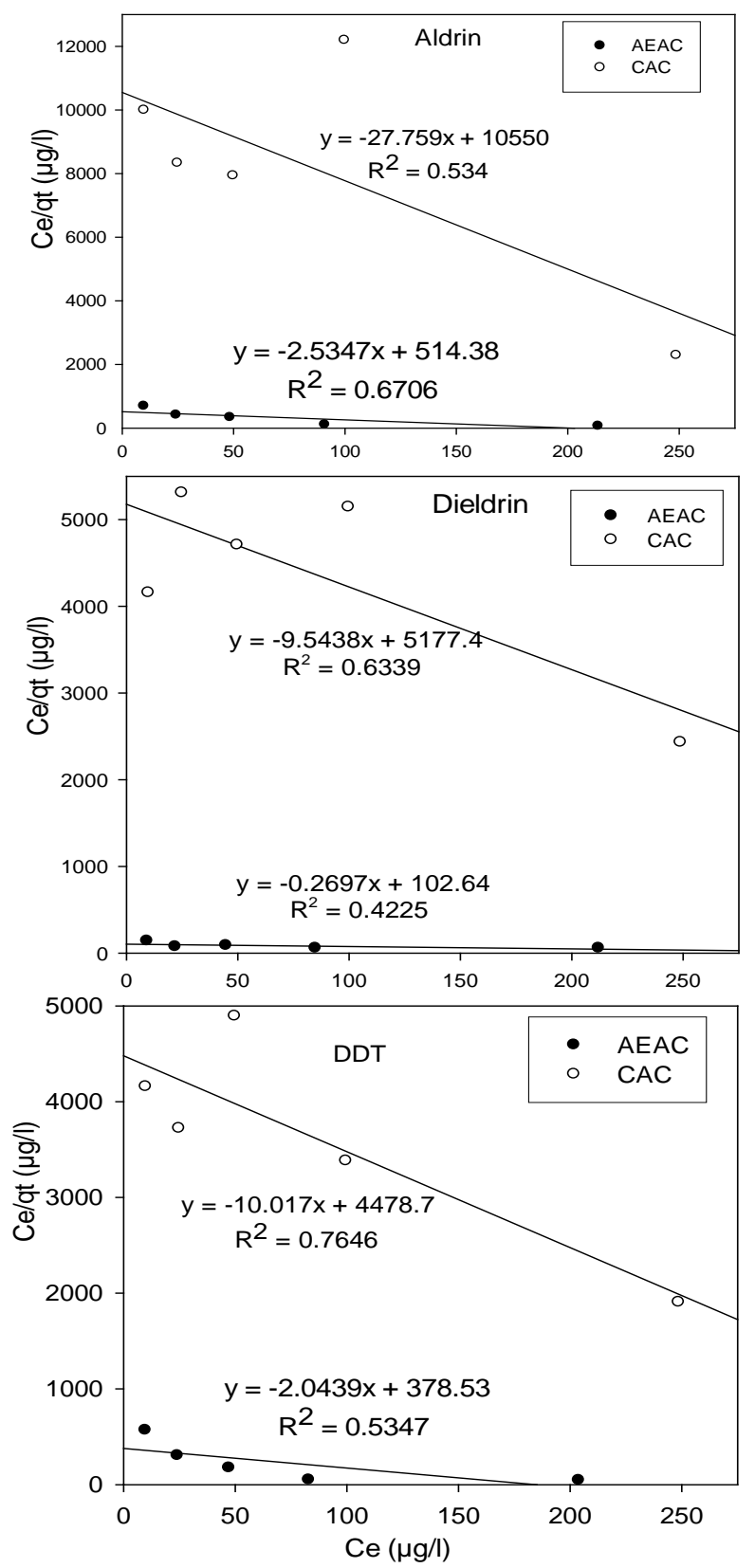

Figure 4. Langmuir adsorption isotherm for organochlorine pesticides (Aldrin, Dieldrin and DDT) onto AEAC and CAC adsorbents ( $\mathrm{pH} 7$; Contact time $2 \mathrm{~h}$; temperature $25^{\circ} \mathrm{C}$, rpm 180 ).

Table 2. Langmuir and Freundlich isotherm parameters for the adsorption of aldrin, dieldrin and DDT from aqueous solutions to AEAC and CAC.

\begin{tabular}{|c|c|c|c|c|c|c|c|c|c|c|c|c|}
\hline \multirow{3}{*}{$\begin{array}{c}\text { Adsorbent } \\
\text { OPCs }\end{array}$} & \multicolumn{6}{|c|}{ AEAC } & \multicolumn{6}{|c|}{ CAC } \\
\hline & \multicolumn{3}{|c|}{ Langmuir model } & \multicolumn{3}{|c|}{ Freundlich model } & \multicolumn{3}{|c|}{ Langmuir model } & \multicolumn{3}{|c|}{ Freundlich model } \\
\hline & $\mathrm{Q}_{0}(\mu \mathrm{g} / \mathrm{g})$ & b $(L / \mu g)$ & $\mathrm{R}^{2}$ & $\mathrm{~K}_{\mathrm{F}}$ & $\mathrm{n}$ & $\mathrm{R}^{2}$ & $\mathrm{Q}_{0}(\mu \mathrm{g} / \mathrm{g})$ & 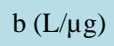 & $\mathrm{R}^{2}$ & $\mathrm{~K}_{\mathrm{F}}$ & $\mathrm{n}$ & $\mathrm{R}^{2}$ \\
\hline Aldrin & -0.395 & -0.005 & 0.671 & $1.81 \times 10^{-4}$ & 0.545 & 0.986 & -0.036 & -0.003 & 0.534 & $3.66 \times 10^{-5}$ & 0.744 & 0.917 \\
\hline Dieldrin & -3.71 & -0.003 & 0.423 & $4.57 \times 10^{-3}$ & 0.785 & 0.987 & -0.105 & -0.002 & 0.634 & $1.36 \times 10^{-4}$ & 0.874 & 0.966 \\
\hline DDT & -0.489 & -0.005 & 0.535 & $1.99 \times 10^{-4}$ & 0.518 & 0.981 & -0.002 & -0.002 & 0.765 & $1.25 \times 10^{-4}$ & 0.823 & 0.975 \\
\hline
\end{tabular}



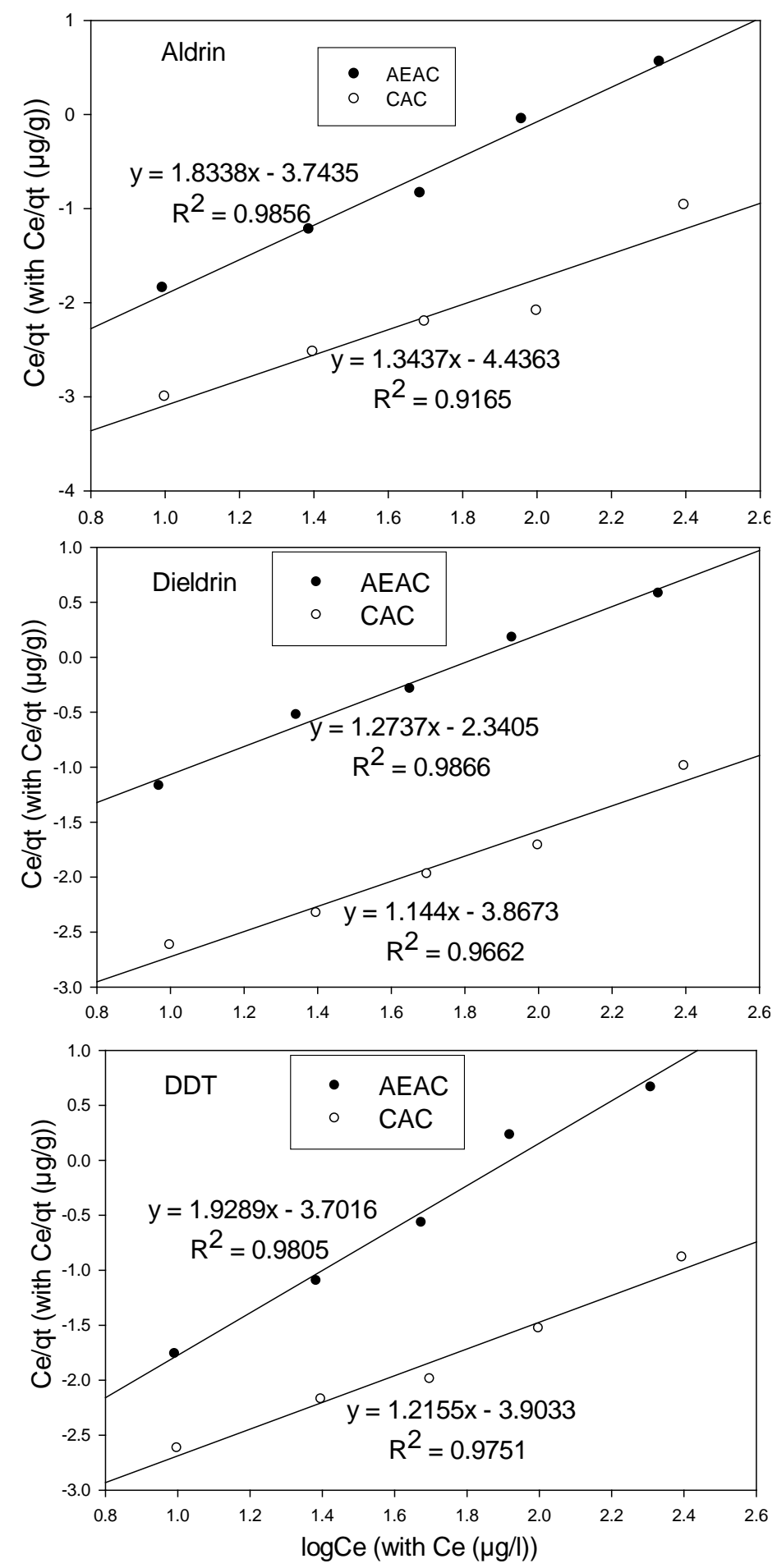

Figure 5. Freundlich adsorption isotherm for organochlorine pesticides (Aldrin, Dieldrin and DDT) onto AEAC and CAC adsorbents ( $\mathrm{pH} 7$; Contact time $2 \mathrm{~h}$; temperature $25^{\circ} \mathrm{C}$, rpm 180 ).

The value of $\mathrm{K}_{\mathrm{F}}$ determines the adsorption capacity of adsorbent at equilibrium concentration in a solution [65] and higher $K_{F}$ values correspond to a higher adsorption capacity. According to the $K_{F}$ values (Table 2), the adsorption capacities of the pesticides studied are higher for dieldrin and DDT than for aldrin in both AEAC and 
CAC adsorbents. Adsorption of pesticides depends on their physico-chemical properties [23], and a more hydrophobic compound has a higher adsorption capacity and thus higher removal efficiency [23]. Similarly, substances with high molar mass have a tendency to be adsorbed more strongly than chemical compounds with low molar mass [65]. Our results are partly in line with these predictions: dieldrin, which has a higher molar mass, adsorbs more than aldrin and DDT, with a lower molar mass. The high adsorption capacity of DDT compared to aldrin might be due to the higher $\log \mathrm{K}_{\mathrm{OW}}$ [23]. The $\mathrm{K}_{\mathrm{F}}$ value also confirms that the AEAC has a higher adsorption capacity than the CAC for the studied pesticides.

The slope $(1 / \mathrm{n})$ for Freundlich's model, which is used for assessing the adsorption intensity of a given substance from water phase adsorbent [65], was greater than 1; this indicates that saturation was not attained. The negative values of the Langmuir isotherm constants indicate the inadequacy of the isotherm model to explain the adsorption process [62] [66]. The adsorption characteristics of the locally prepared AEAC are comparable with the CAC, but the adsorption performance was much better.

\subsection{Adsorption of Pesticides In columns Filtration}

For the purposes of the removal of trace levels of organic pollutants from drinking water, the main concern is whether or not a treatment process can efficiently and economically remove the organochlorine pesticides to acceptable levels from water. Rapid small-scale column testing is an inexpensive, accelerated testing method that can be used to determine the adsorptive characteristics for large-scale adsorption using small column studies. The advantage of such rapid small-scale testing over pilot testing is the time savings [67]. Other major advantages are cost savings, reduced water requirements, and the fact that extensive isotherm and kinetic studies are not necessary. Therefore, the results of such small-scale testing can be scaled up to aid in the design of a medium-scale water treatment plants at each household communities.

Flushing distilled water through the column results in removal of the turbidity from AEAC. During flushing $0.2 \mathrm{~L}$ was found to be sufficient for AEAC to reduce turbidity to less than $5 \mathrm{NTU}$, which is in the range of international standards assumed acceptable [68]. Fixed doses of $20 \mu \mathrm{g} / \mathrm{L}$ of pesticides spiked in $25 \mathrm{ml}$ of water were used in experiments with different doses of AEAC. These doses varied from 3 to $11 \mathrm{~g}$. The findings also showed that the percentage of pesticide adsorbed increased as the amount of AEAC in the column increased. Seven grams of AEAC was sufficient to remove greater than 92\% of aldrin and dieldrin, and greater than $85 \%$ of DDT, which is comparable with the batch experiments mentioned above.

\subsection{Breakthrough of Pesticides in Column Filtration with AEAC}

Breakthrough of the three pesticides studied for a column was observed after filtering $2.5 \mathrm{~L}$ of water; the first pesticides to appear in the filtered water were aldrin and DDT. This means that roughly $1 \mathrm{~kg}$ of ACAC is needed to filter $10 \mathrm{~L}$ of contaminated water, corresponding small slices of the widely available A. etbaica wood. Although care should be taken about the adsorption capacity for other pesticides (and, potentially, other micropollutants) that may occur in surface waters, the method is postulated to be feasible and safe for production of potable water from sources contaminated with pesticides.

\subsection{Cost Comparison}

A distinct advantage of using AEAC as adsorbent is that it is cheaper than CAC available in Ethiopia which costs 373000.00 Ethiopian Birr/ton or US\$20687.74/ton. The AEAC costs 3000.00 Ethiopian Birr/ton or US\$ 166.39/ton, and is available at the local markets, so that extra costs for labor and transport are avoided. Another advantage is that this material can be locally made even in remote communities, at low cost as the materials do not have to be imported and local markets and production are stimulated.

The total cost of activated carbon adsorption also includes construction costs of the water purification unit, and regeneration of activated carbon. The former costs are similar for both types of activated carbon, whereas the regeneration costs depend on the runtime of an adsorption column when operated in continuous mode. Although this aspect was beyond the scope of the work presented here, it can be expected that regeneration costs are similar for the two types of activated carbon, given the fact that they have been shown to have a comparable performance in batch experiments. Therefore, the difference in cost is mainly related to the difference in cost of the activated carbon. 


\section{Conclusion}

This study investigates the adsorption of organochlorine pesticides: aldrin, dieldrin and DDT onto AEAC and CAC. The extent of pesticide removal increased with decreasing initial concentration of pesticides and increased with increasing adsorbent mass. The adsorptions of pesticides on the studied adsorbents (AEAC and CAC) were influenced by the physico-chemical properties of pesticides and adsorbents such as molecular weight, $\log \mathrm{K}_{\text {ow }}$, and hydrophobic characteristics of pesticides; and surface morphology of the adsorbents. The equilibrium data in this study were fitted with the Freundlich isotherm model. Our results indicate that the AEAC used in this investigation, which is freely, abundantly and locally available, could be used as an efficient and alternative adsorbent in water treatments. Finally, a cost comparison of AEAC and CAC leads to the conclusion that AEAC is a more effective and low-cost adsorbent that can be used for the removal of the studied pesticides and likely other impurities from water. The AEAC can also be produced and used by communities living in remote areas.

\section{Acknowledgements}

This study was financially supported by the Vlaamse Interuniversitaire Raad-University Development Cooperation (VLIR-UOS), Belgium in collaboration with Mekelle University, Ethiopia. The authors thank Mrs. Christine Wouters, Mrs. Michele Vanroelen and Mrs. Ruixin Zhang for their kind support in pesticide, metal and surface physical morphology (SEM) analysis.

\section{References}

[1] Zhang, W., Ye, Y., Tong, Y., Ou, L., Hu, D. and Wang, X. (2011) Contribution and Loading Estimation of Organochlorine Pesticides from Rain and Canopy through Fall to Runoff in an Urban Environment. Journal of Hazardous Materials, 185, 801-806. http://dx.doi.org/10.1016/j.jhazmat.2010.09.091

[2] Ayranci, E. and Hoda, N. (2005) Adsorption Kinetics and Isotherms of Pesticides onto Activated Carbon-Cloth. Chemosphere, 60, 1600-1607. http://dx.doi.org/10.1016/j.chemosphere.2005.02.040

[3] Kuster, M., López de Alda, M. and Barceló, D. (2009) Liquid Chromatography-Tandem Mass Spectrometric Analysis and Regulatory Issues of Polar Pesticides in Natural and Treated Waters. Journal of Chromatography A, 1216, 520-529. http://dx.doi.org/10.1016/j.chroma.2008.08.031

[4] Agrawal, A. and Sharma, B. (2010) Pesticides Induced Oxidative Stress in Mammalian Systems—Review Article. International Journal of Biological and Medical Research, 1, 90-104.

[5] Guan, Y., Wang, J., Ni, H. and Zeng, E.Y. (2009) Organochlorine Pesticides and Polychlorinated Biphenyls in Riverine Runoff of the Pearl River Delta, China: Assessment of Mass Loading Input Source and Environmental Fate. Environmental Pollution, 157, 618-624. http://dx.doi.org/10.1016/j.envpol.2008.08.011

[6] Nakata, H., Kawazoe, M., Arizono, K., Abe, S., Kitano, T. and Shimada, H. (2002) Organochlorine Pesticides and Polychlorinated Biphenyl Residues in Foodstuffs and Human Tissues from China: Status of Contamination, Historical Trend, and Human Dietary Exposure. Archives of Environmental Contamination and Toxicology, 43, 473-480. http://dx.doi.org/10.1007/s00244-002-1254-8

[7] Poon, B.H.T., Leung, C.K.M., Wong, C.K.C. and Wong, M.H. (2005) Polychlorinated Biphenyls and Organochlorine Pesticides in Human Adipose Tissue and Breast Milk Collected in Hong Kong. Archives of Environmental Contamination and Toxicology, 49, 274-282. http://dx.doi.org/10.1007/s00244-004-0111-3

[8] Asawasinsopon, R., Prapamontol, T., Prakobvitayakit, O., Vaneesorn, Y., Mangklabruks, A. and Hock, B. (2006) The Association between Organochlorine and Thyroid Hormone Levels in Cord Serum: A Study from Northern Thailand. Environment International, 32, 554-559. http://dx.doi.org/10.1016/j.envint.2006.01.001

[9] Dalvie, M.A., Myers, J.E., Thompson, M.L., Robins, T.G., Dyer, S., Riebow, J., Molekwa, J., Jeebhay, M., Millar, R. and Kruger, P. (2004) The Long-Term Effects of DDT Exposure on Semen, Fertility, and Sexual Function of Malaria Vector-Control Workers in Limpopo Province, South Africa. Environmental Research, 96, 1-8. http://dx.doi.org/10.1016/j.envres.2003.09.002

[10] Dalvie, M.A., Myers, J.E., Thompson, M.L., Dyer, S., Robins, T.G., Omar, S., Riebow, J., Molekwa, J., Kruger, P. and Millar, R. (2004) The Hormonal Effects of Long-Term DDT Exposure on Malaria Vector-Control Workers in Limpopo Province, South Africa. Environmental Research, 96, 9-19. http://dx.doi.org/10.1016/j.envres.2003.09.003

[11] Hinck, J.E., Norstrom, R.J., Orazio, C.E., Schmitt, C.J. and Tillitt, D.E. (2009) Persistence of Organochlorine Chemical Residues in Fish from the Tombigbee River (Alabama, USA): Continuing Risk to Wildlife from a Former DDT Manufacturing Facility. Environmental Pollution, 157, 582-591. http://dx.doi.org/10.1016/j.envpol.2008.08.021

[12] Hileman, E. (1994) Environmental Estrogens Linked to Reproductive Abnormalities and Cancer. Chemical and Engi- 
neering News, 72, 19-23. http://dx.doi.org/10.1021/cen-v072n005.p019

[13] Giannandrea, F., Gandini, L., Paoli, D., Turci, R. and Figa-Talamanca, I. (2011) Pesticide Exposure and Serum Organochlorine Residuals among Testicular Cancer Patients and Healthy Controls. Journal of Environmental Science and Health, Part B, 46, 780-787.

[14] ATSDR (2000) Agency for Toxic Substances and Disease Registry. Toxicological Profile for Aldrin/Dieldrin. (Update). Draft for Public Comment, US Department of Health and Human Services, Public Health Service, Atlanta.

[15] ATSDR (2002) Agency for Toxic Substances and Disease Registry. Toxicological Profile for DDT, DDE, DDD. U.S. Department of Health and Human Services, Public Health Service, Atlanta.

[16] Jiang, Y., Wang, X., Jia, Y., Wang, F., Wu, M., Sheng, G. and Fu, J. (2009) Occurrence, Distribution and Possible Sources of Organochlorine Pesticides in Agricultural Soil of Shanghai, China. Journal of Hazardous Materials, 170, 989-997. http://dx.doi.org/10.1016/j.jhazmat.2009.05.082

[17] Barriada-Pereira, M., González-Castro, M.J., Muniategui-Lorenzo, S., López-Mahía, P., Prada-Rodríguez, D. and Fernández-Fernández, E. (2005) Organochlorine Pesticides Accumulation and Degradation Products in Vegetation Samples of a Contaminated Area in Galicia (NW Spain). Chemosphere, 58, 1571-1578. http://dx.doi.org/10.1016/j.chemosphere.2004.10.016

[18] Loewy, R.M., Monza, L.B., Kirs, V.E. and Savini, M.C. (2011) Pesticide Distribution in an Agricultural Environment in Argentina. Journal of Environmental Science and Health, Part B, 46, 662-670.

[19] Wandiga, S.O. (2001) Use and Distribution of Organochlorine Pesticides: The Future in Africa. Pure and Applied Chemistry, 73, 1147-1155. http://dx.doi.org/10.1351/pac200173071147

[20] Westbom, R., Hussen, A., Megersa, N., Retta, N., Mathiasson, L. and Björklund, E. (2008) Assessment of Organochlorine Pesticide Pollution in Upper Awash Ethiopian State Farm Soils Using Selective Pressurised Liquid Extraction. Chemosphere, 72, 1181-1187. http://dx.doi.org/10.1016/j.chemosphere.2008.03.041

[21] Mandavilli, A. (2006) DDT Returns. Nature Medicine, 12, 870-871. http://dx.doi.org/10.1038/nm0806-870

[22] Pontius, F.W. (1990) Water Quality and Treatment. 4th Edition, McGraw-Hill Inc., New York.

[23] Thuy, P.T., Moons, K., Van Dijk, J.C., Anh, N.V. and Van der Bruggen, B. (2008) To What Extent Are Pesticides Removed from Surface Water during Coagulation-Flocculation? Water and Environment Journal, 22, 217-223. http://dx.doi.org/10.1111/j.1747-6593.2008.00128.x

[24] Baczynski, T.P., Pleissner, D. and Grotenhuis, T. (2010) Anaerobic Biodegradation of Organochlorine Pesticides in Contaminated Soil—Significance of Temperature and Availability. Chemosphere, 78, 22-28. http://dx.doi.org/10.1016/j.chemosphere.2009.09.058

[25] Chiu, T.C., Yen, J.H., Liu, T.L. and Wang, Y.S. (2004) Anaerobic Degradation of the Organochlorine Pesticides DDT and Heptachlor in River Sediment of Taiwan. Bulletin of Environmental Contamination and Toxicology, 72, 821-828. http://dx.doi.org/10.1007/s00128-004-0318-z

[26] Senthilnathan, J. and Philip, L. (2009) Removal of Mixed Pesticides from Drinking Water System by Photodegradation Using Suspended and Immobilized $\mathrm{TiO}_{2}$. Journal of Environmental Science and Health, Part B, 44, 262-270. http://dx.doi.org/10.1080/03601230902728328

[27] Reungoat, J., Macova, M., Escher, B.I., Carswell, S., Mueller, J.F. and Keller, J. (2010) Removal of Micropollutants and Reduction of Biological Activity in a Full Scale Reclamation Plant Using Ozonation and Activated Carbon Filtration. Water Research, 44, 625-637. http://dx.doi.org/10.1016/j.watres.2009.09.048

[28] Humbert, H., Gallard, H., Suty, H. and Croue, J. (2008) Natural Organic Matter (NOM) and Pesticides Removal Using a Combination of Ion Exchange Resin and Powdered Activated Carbon (PAC). Water Research, 42, 1635-1643. http://dx.doi.org/10.1016/j.watres.2007.10.012

[29] Lafi, W.K. and Al-Qodah, Z. (2006) Combined Advanced Oxidation and Biological Treatment Processes for the Removal of Pesticides from Aqueous Solutions. Journal of Hazardous Materials, 137, 489-497. http://dx.doi.org/10.1016/j.jhazmat.2006.02.027

[30] Badawy, M.I., Ghaly, M.Y. and Gad-Allah, T.A. (2006) Advanced Oxidation Processes for the Removal of Organophosphorus Pesticides from Wastewater. Desalination, 194, 166-175. http://dx.doi.org/10.1016/j.desal.2005.09.027

[31] Moons, K. and Van der Bruggen, B. (2006) Removal of Micropollutants during Drinking Water Production from Surface Water with Nanofiltration. Desalination, 199, 245-247. http://dx.doi.org/10.1016/j.desal.2006.03.060

[32] Yangali-Quintanilla, V., Maeng, S.K., Fujioka, T., Kennedy, M. and Amy, G. (2010) Proposing Nanofiltration as Acceptable Barrier for Organic Contaminants in Water Reuse. Journal of Membrane Science, 362, 334-345. http://dx.doi.org/10.1016/j.memsci.2010.06.058

[33] Oliveira, L.C.A., Pereira, E., Guimaraes, I.R., Vallone, A., Pereira, M., Mesquita, J.P. and Sapag, K. (2009) Preparation of Activated Carbons from Coffee Husks Utilizing $\mathrm{FeCl}_{3}$ and $\mathrm{ZnCl}_{2}$ as Activating Agents. Journal of Hazardous 
Materials, 165, 87-94. http://dx.doi.org/10.1016/j.jhazmat.2008.09.064

[34] Salman, J.M. and Hameed, B.H. (2010) Removal of Insecticide Carbofuran from Aqueous Solution by Banana Stalks Activated Carbon. Journal of Hazardous Materials, 176, 814-819. http://dx.doi.org/10.1016/i.jhazmat.2009.11.107

[35] Ormad, M.P., Miguel, N., Claver, A., Matesanz, J.M. and Ovelleiro, J.L. (2008) Pesticides Removal in the Process of Drinking Water Production. Chemosphere, 71, 97-106. http://dx.doi.org/10.1016/j.chemosphere.2007.10.006

[36] Faust, S.D. and Aly, O.M. (1987) Adsorption Process for Water Treatment. Butterworths Publishers, Stoneham.

[37] Bhatnagar, A. and Sillanpää, M. (2010) Utilization of Agro-Industrial and Municipal Waste Materials as Potential Adsorbents for Water Treatment-A Review. Chemical Engineering Journal, 157, 277-296. http://dx.doi.org/10.1016/j.cej.2010.01.007

[38] Bansal, R.C. and Goyal, M. (2005) Activated Carbon Adsorption. CRC press, New York. http://dx.doi.org/10.1201/9781420028812

[39] Gupta, V.K. and Suhas (2009) Application of Low-Cost Adsorbents for Dye Removal—A Review. Journal of Environmental Management, 90, 2313-2342. http://dx.doi.org/10.1016/j.jenvman.2008.11.017

[40] Thuy, P.T., Anh, N.V. and Van der Bruggen, B. (2012) Evaluation of Two Low-Cost-High-Performance Adsorbent Materials in the Waste-to-Product Approach for the Removal of Pesticides from Drinking Water. CLEAN-Soil, Air, Water, 40, 246-253. http://dx.doi.org/10.1002/clen.201100209

[41] Gebrekidan, A., Nicolai, H., Vincken, L., Teferi, M., Asmelash, T., Dejenie, T., Zerabruk, S., Gebrehiwet, K., Bauer, H., Deckers, J., Luis, P., De Meester, L. and Van der Bruggen, B. (2013) Filtration over Cactus Pear Leaves Material Efficiently Removes Pesticides from Water: A Cheap and Natural Method for Small-Scale Water Purification in SemiArid Regions. CLEAN—Soil, Air, Water, 41, 335-343. http://dx.doi.org/10.1002/clen.201200042

[42] Adachi, A., Ikeda, C., Takagi, S., Fukao, N., Yoshie, E. and Okano, T. (2001) Efficiency of Rice Bran for Removal of Organochlorine Compounds and Benzene from Industrial Wastewater. Journal of Agricultural and Food Chemistry, 49, 1309-1314. http://dx.doi.org/10.1021/jf001147c

[43] El Bakouri, H., Morillo, J., Usero, J. and Ouassini, A. (2008) Potential Use of Organic Waste Substances as an Ecological Technique to Reduce Pesticide Ground Water Contamination. Journal of Hydrology, 353, 335-342. http://dx.doi.org/10.1016/j.jhydrol.2008.02.019

[44] Nieto-Delgado, C., Terrones, M. and Rangel-Mendez, J.R. (2011) Development of Highly Microporous Activated Carbon from the Alcoholic Beverage Industry Organic By-Products. Biomass and Bioenergy, 35, 103-112. http://dx.doi.org/10.1016/j.biombioe.2010.08.025

[45] Akhtar, M., Hasany, S.M., Bhanger, M.I. and Iqbal, S. (2007) Low Cost Sorbents for the Removal of Methyl Parathion Pesticide from Aqueous Solutions. Chemosphere, 66, 1829-1838. http://dx.doi.org/10.1016/j.chemosphere.2006.09.006

[46] Fenoll, J., Ruiz, E., Flores, P., Vela, N., Hellín, P. and Navarro, S. (2011) Use of Farming and Agro-Industrial Wastes as Versatile Barriers in Reducing Pesticide Leaching Through Soil Columns. Journal of Hazardous Materials, 187, 206-212. http://dx.doi.org/10.1016/j.jhazmat.2011.01.012

[47] El Bakouri, H., Morillo, J., Usero, J. and Ouassini, A. (2009) Natural Attenuation of Pesticide Water Contamination by Using Ecological Adsorbents: Application for Chlorinated Pesticides Included in European Water Framework Directive. Journal of Hydrology, 364, 175-181. http://dx.doi.org/10.1016/j.jhydrol.2008.10.012

[48] Lim, Y.N., Shaaban, M.G. and Yin, C.Y. (2008) Removal of Endosulfan from Water Using Oil Palm Shell Activated Carbon and Rice Husk Ash. Journal of Oil Palm Research, 20, 527-532.

[49] Kadirvelu, K., Palanival, M., Kalpana, R. and Rajeswari, S. (2000) Activated Carbon from an Agricultural By-Product, for the Treatment of Dyeing Industry Wastewater. Bioresource Technology, 74, 263-265. http://dx.doi.org/10.1016/S0960-8524(00)00013-4

[50] Thulin, M. (1989) Fabaceae. In: Hedberg, I. and Edwards, S., Eds., Flora of Ethiopia, Vol. 3. Pittosporaceae to Araliaceae, the Ethiopia National Herbarium, Addis Ababa.

[51] Biscoe, M.L., Mutero, C.M. and Kramer, R.A. (2005) Current Policy and Status of DDT Use for Malaria Control in Ethiopia, Uganda, Kenya and South Africa. Working Paper 95, IWMI, Colombo.

[52] Giles, C.H., MacEwan, T.H., Nakhwa, S.N. and Smithm, D. (1960) Studies in Adsorption. Part XI. A System of Classification of Solution Adsorption Isotherms and Its Use in Diagnosis of Adsorption Mechanisms and in Measurement of Specific Surface Areas of Solids. Journal of the Chemical Society, 3973-3993. http://dx.doi.org/10.1039/jr9600003973

[53] Sawalha, M.F., Peralta-Videa, J.R., Duarte-Gardea, M. and Gardea-Torresdey, J.L. (2008) Removal of Copper, Lead and Zinc from Contaminated Water by Saltbush Biomass: Analysis of the Optimum Binding, Stripping, and Binding Mechanism. Bioresource Technology, 99, 4438-4444. http://dx.doi.org/10.1016/j.biortech.2007.08.070

[54] Langmuir, I. (1918) The Adsorption of Gases on Plane Surfaces of Glass, Mica and Platinum. Journal of the American 
Chemical Society, 40, 1361-1403. http://dx.doi.org/10.1021/ja02242a004

[55] Langmuir, I. (1916) The Constitution and Fundamental Properties of Solids and Liquids. Journal of the American Chemical Society, 38, 2221-2295. http://dx.doi.org/10.1021/ja02268a002

[56] Freundlich, H.M.F. (1906) Über die adsorption in lösungen (Adsorption in Solution). Zeitschrift für Physikalische Chemie, 57, 385-490.

[57] Gupta, V.K., Jain, C.K., Ali, I., Chandra, S. and Agarwal, S. (2002) Removal of Lindane and Malathion from Wastewater Using Bagasse Fly Ash-A Sugar Industry Waste. Water Research, 36, 2483-2490. http://dx.doi.org/10.1016/S0043-1354(01)00474-2

[58] Pal, S., Lee, K.H., Kim, J.U., Han, S.H. and Song, J.M. (2006) Adsorption of Cyanuric Acid on Activated Carbon from Aqueous Solution: Effect of Carbon Surface Modification and Thermodynamic Characteristics. Journal of Colloid and Interface Science, 250, 93-98.

[59] Kilic, M., Apaydin-Varol, E. and Pütün, A.E. (2011) Adsorptive Removal of Phenol from Aqueous Solutions on Activated Carbon Prepared from Tobacco Residues: Equilibrium, Kinetics and Thermodynamics. Journal of Hazardous Materials, 189, 397-403. http://dx.doi.org/10.1016/j.jhazmat.2011.02.051

[60] Gupta, V.K., Gupta, B., Rastogi, A., Agarwal, S. and Nayak, A. (2011) Pesticides Removal from Wastewater by Activated Carbon Prepared from Waste Rubber Tire. Water Research, 45, 4047-4055. http://dx.doi.org/10.1016/j.watres.2011.05.016

[61] Tan, I.A.W., Ahmad, A.L. and Hameed, B.H. (2009) Fixed-Bed Adsorption Performance of Oil Palm Shell-Based Activated Carbon for Removal of 2,4,6-Trichlorophenol. Bioresource Technology, 100, 1494-1496. http://dx.doi.org/10.1016/j.biortech.2008.08.017

[62] Ozcan, S., Tor, A. and Aydin, M.E. (2011) Removal of Organochlorine Pesticides from Aqueous Solution by Using Neutralized Red Mud. CLEAN—Soil, Air, Water, 39, 972-979. http://dx.doi.org/10.1002/clen.201000596

[63] Kumar, P.S., Ramalingam, S., Senthamarai, C., Niranjanaa, M., Vijayalakshmi, P. and Sivanesan, S. (2010) Adsorption of Dye from Aqueous Solution by Cashew Nut Shell: Studies on Equilibrium Isotherm, Kinetics and Thermodynamics of Interactions. Desalination, 261, 52-60. http://dx.doi.org/10.1016/j.desal.2010.05.032

[64] Hameed, B.H. (2007) Equilibrium and Kinetics Studies of 2,4,6-Trichlorophenol Adsorption onto Activated Clay. Colloids and Surfaces A: Physicochemical and Engineering Aspects, 307, 45-52. http://dx.doi.org/10.1016/j.colsurfa.2007.05.002

[65] Katarzyna, I. (2009) Selection of Sorbent for Removing Pesticides during Water Treatment. Journal of Hazardous Materials, 169, 953-957. http://dx.doi.org/10.1016/j.jhazmat.2009.04.061

[66] Ozturk, N. and Bektas, T.E. (2004) Nitrate Removal from Aqueous Solution by Adsorption onto Various Materials. Journal of Hazardous Materials, 112, 155-162. http://dx.doi.org/10.1016/j.jhazmat.2004.05.001

[67] Crittenden, J.C., Berrigan, J.K., Hand, D.W. and Lykins Jr., B.W. (1987) Design of Rapid Fixed Bed Adsorption Tests for Non Constant Diffusivities. Journal of Environmental Engineering, 113, 243-259. http://dx.doi.org/10.1061/(ASCE)0733-9372(1987)113:2(243)

[68] WHO (2006) Guidelines for Drinking-Water Quality. World Health Organization, Geneva. 